\title{
MODIFICATION OF JURGEN HABERMAS THOUGHT IN BUSINESS MANAGEMENT PRACTICES: AN EMPIRICAL STUDY AT MONDRAGON CORP
}

\author{
Andhika Rahmat Saputra*), R. Iqbal Robbie ${ }^{* 11}$, and M. Fitrah Ashary Bangun ${ }^{*}$ \\ *) Faculty of Economics and Business, Universitas Muhammadiyah Malang \\ J1. Raya Tlogomas No. 246 Kota Malang, Indonesia
}

\begin{abstract}
This study aims to briefly review the thoughts of Jurgen Habermas, the German philosopher at the Frankfurt School of Religion with his critical philosophy, especially those concerning social thoughts by comparing them to management science so that management science in theory and practice can be critical. Data processing uses descriptive analysis with a deconstruction paradigm, looking more sharply to give new and critical meanings to the interpretation of Habermas' thought. The text is understood and rearranged from a different perspective of thought, after discovering the foundation and philosophical structure of Habermas' thought, the researcher contributes thoughts in management science so that he can include it in the implementation of the Mondragon company. The results of this study prove that the idea of critical management science supports people's views regarding profitability and the strategy of the Mondragon company in a brief conceptualization reflecting the vision, mission, and values that adhere to humanity, equality of emancipatory values , and solidarity. The managerial implications are addressed by methods that are democratic and prioritize the social side to increase profitability
\end{abstract}

Keywords: habermas, strategic management, democratic, mondragon

\begin{abstract}
Abstrak: Penelitian ini bertujuan melakukan critical review secara ringkas pemikiran Jurgen Habermas, filosuf Jerman pada Madzhab Frankfurt dengan filsafat kritisnya terutama yang menyangkut pemikiran-pemikiran sosial dengan membandingkannya pada ilmu manajemen sehingga ilmu manajemen secara teori dan praktik dapat bersifat kritis. Pengolahan data menggunakan analisis deskriptif dengan paradigma dekonstruksi, melihat secara lebih tajam untuk memberikan makna baru dan kritis atas penafsiran pemikiran Habermas tersebut. Teks dipahami dan disusun ulang dengan sudut pandang pemikiran yang berbeda, setelah menemukan pondasi serta strukturfilosofis daripemikiran Habermas, peneliti memberikan sumbangan pemikiran dalam ilmu manajemen sehingga dapat memasukkannya pada implementasi dari perusahaan Mondragon. Hasil penelitian ini membuktikan bahwa gagasan ilmu manajemen kritis menunjang pandangan orang terkait profitabilitas serta strategi dari perusahaan Mondragon dalam konseptualisasi ringkas mencerminkan visi, misi serta nilai-nilai yang berpegang pada kemanusiaan, persamaaan nilai emansipatoris serta solidaritas. Implikasi manajerial ditujukan dengan metode yang demokratis dan mengutamakan sisi sosial untuk peningkatan profitabilitas.
\end{abstract}

Kata kunci: habermas, manajemen strategi, demokratis, mondragon

\footnotetext{
${ }^{1}$ Corresponding author:

Email: iqbal_robbie@umm.ac.id
} 


\section{INTRODUCTION}

Based on etymology, management is taken from ancient French, namely management which means the art of organizing and implementing. Management can also be defined as planning, coordinating, organizing, and controlling resources to achieve goals efficiently and effectively. According to (Griffin, 2007) management is a process of organizing, coordinating, planning, and controlling resources to achieve goals efficiently and effectively. Efficient is where an existing task has been carried out in an organized, correct and according to schedule, while being effective itself means that a goal can be achieved following what has been planned (Griffin, 2007).

According to (ROBBINS, 2016), the notion of management is a socio-technical process that utilizes resources, influence, human action, and change facilities to achieve organizational goals. In general, researchers take the definition that management science is an art as well as a science that studies planning, organizing, implementing, and controlling effectively and efficiently to achieve common goals. Management science is also a multidisciplinary science because management science studies several perspectives from other scientific studies. Therefore, multidisciplinary management science can be said to have elements such as natural sciences and social sciences. However, management science often in practice uses a perspective that is too positivistic so that management science is ideologized in one pole and becomes uncritical. Positivism and scientism have been radically criticized in the Dialectic der Aufklarung by Horkheimer and Adorno and One Dimensional Man by Herbert Marcuse (Hardiman, 2004). ideological, later called by Horkheimer and Adorno as institutional ratio and Marcuse called it technological rationality for them this form of consciousness signifies the existence of an oppressive structure in modern society(Adorno, 2014). Then they manifested their criticism of traditional theories by looking for the roots of positivism that used natural sciences to study concrete human social life such as culture, politics, and of course social. Then in their book Dialectic der Aufklarung Horkheimer and Adorno give an equally radical critique of the cultural industry, companies, and even their managerial aspects as instruments that freeze society(Adorno, 2014).

The Mondragon company is a leading business group in the Basque Country and one of the largest companies in Spain. The company has operations worldwide, with
141 production plants in 37 countries, commercial business in 53 countries, and sales in more than 150 countries. The mission of the Mondragon Company is encapsulated in its corporate values, namely: inter cooperation, grassroots management, corporate social responsibility, innovation, democratic organization, education, and social transformation (Mondragon, 2020). The organizational model of Mondragon's company uses democratic methods in its corporate organization, and its objectives are work, the personal and professional progress of its workers, and the development of its community (Nuris, 2016).

The researcher uses the perspective of Jurgen Habermas as a grand theory in this study. In short, the predecessors of Jurgen Habermas such as Horkheimer, Adorno, and even Marcuse experienced a deadlock to find a solution as a liberator of human rationality (Hardiman, 2004). As a result, Habermas with his diligence and high interest in the knowledge offered a new paradigm to answer the dilemmas of his predecessors, namely the communication paradigm as a critique of the subject philosophy (Irfaan, 2009). The perspective of Jurgen Habermas, which starts from a description of the relationship between interests and knowledge, becomes an accurate epistemological basis as well as a criticism of management science starting from the description of two basic dimensions consisting of knowledge and orientation of human action which ultimately requires a dimension and knowledge. critical to accommodate these two interests so that interests can also be achieved with an emancipatory orientation. One of Habermas's thoughts is the sociological theory of action, with the Communicative dimension of Habermas, which suggests that humans interpersonally carry out actions or deeds in line with the agreed consensus, this consensus can occur if the language is easily understood by the whole community (Priastana, 2012).

The Mondragon company is a company that has a praxis or emancipatory orientation that successfully combines the benefits of consensus with the human dimension (Maulana, 2020). Finally, we will find management science as a critical science and has emancipatory importance as its praxis. After the reconstruction of management science by incorporating the perspective of Jurgen Habermas, the researcher will show the suitability of these findings with their implementation at the Mondragon company. Based on the elaboration on the background of the researcher determining this study aims to briefly review Jurgen Habermas's thoughts with 
the deconstruction paradigm. After discovering the foundation and philosophical structure of Habermas' thought, the researcher contributes thoughts in management science so that he can include them in the implementation of the Mondragon company.

\section{METHODS}

Research and efforts to discover the Habermas concept are of course indispensable in order to help achieve the achievements of companies in Indonesia such as Mondragon. The concept of performance is very important, because if this concept is put into practice, it can move company management and other parties to interact integrally to move towards the goals they want. For this reason, this study pays great attention to finding the Mondragon concept. This research, in an effort to construct habermas thinking towards the concept of performance, uses a deconstruction perspective. This point of view actually emphasizes the integration of a concept, namely the integration of the practical aspects, power and emancipation of Habermas. Therefore, human characteristics, local wisdom, and social welfare in this study become an inseparable unit. In particular, this research takes the Habermas concept and is put into practice for Mondragon. The data used in this study came partly from nonempirical data, partly from literature and inspirational data from researchers. In non-positivistic research, social theories are often used as tools for analyzing data, such as theory critical, ethnography, phenomenology, and others. Not only that, even culture, religion, and metaphors (figuratively) are also used as an analytical tool.

Theory and reality are two different things. Reality is something that is objective and what it is (as it is). While theory is the result of understanding humans over reality by using inherent subjective glasses in itself, namely the combination of the five senses, experience, rational reason, feelings, and intuition. Reality can be photographed from a variety of point of view (paradigm) which is on finally came up with a different theory. All the resulting theories must have truth, but only relatively true. This research aims to build habermas concept of thought with Mondragon's framework in practice using the values of cooperation and social emancipation. This research is not specific take research sites, for example the Mondragon company, as a base empirical data collection. But on the contrary, This research puts more emphasis on attempt to construct the concept of performance from a perspective Habermas scholarship, although in several parts it is presented secondary data to support argumentation.

This research was conducted for three months, October, November, and December 2020. This paper using a qualitative approach based on deconstruct paradigm using content analysis as described by Bengtsson (2016) because it criticizes Habermas thinking in terms of management. Secondary data obtained from books, journals, and the website of Mondragon company discussed the thought of Jurgen Habermas. Content analysis, according to Krippendorff (2004), is a research technique for drawing reliable and accurate inferences from text (or other meaningful matter) to the context in which it is used. Content analysis is a four-stage process that can be applied to any form of data (written texts from any source). First, the decontextualization (identify and familiarized data) this paper using the keyword Jurgen Habermas in several sources such as books and journals. The second is recontextualization (compare with the original data, matching data based on the journal, and other secondary data). Third, is categorization (identify a homogenous group of topics or themes about Jurgen Habermas in Mondragon company). The last, compilation, is drawing a realistic conclusion about Jurgen Habermas's thought in business management practices towards the Mondragon company. Research Proposition: how the science of management with Jurgen Habermas thinking is especially oriented towards the Mondragon company. Research framework in Figure 1.

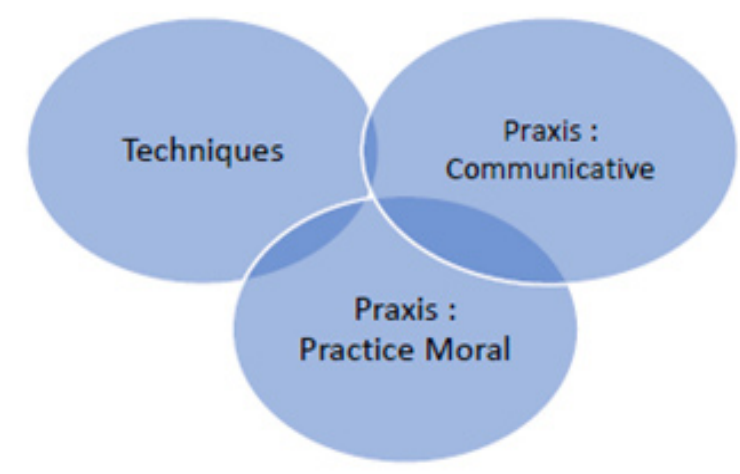

Figure 1. Research framework 


\section{RESULTS}

\section{The human dimension: Habermas's perspective on interests and knowledge}

Humans have two types of interests and basic knowledge which researchers will classify as two dimensions, namely: the technical-control dimension and the moral-practical dimension. The interest and knowledge related to technical control which is oriented to success in its technical control in nature can be seen by the advancement of technology that supports its success in controlling the objective nature. Meanwhile, the interests and practical moral knowledge have a circulation in the interactions between subjects carried out to achieve mutual understanding or consensus as we can see in culture, socio-politics, and various forms of products of normative agreement between other humans (Hardiman, 2018). constraints on the technical control dimension also have a very significant effect on our moral-practical sphere (Irfaan, 2009).

According to Habermas, if we view labor forces or production activities in the objective realm of work relations as a learning mechanism or structure of a species, it can also be said that humans as a species learn not only in the dimension of technical knowledge for objective nature which is indeed a the determinant factor for the development of workforces or production but also the learning process also occurs in the practical moral dimension which determines the reciprocal structure (Hardiman 2010). After finding the partialization and significance of the two dimensions, we can finally lead to two practices on both, namely: work and communication (Klein and Huynh, 2004).

This division of precise practice aims at refreshing Marx's thinking on the conflicted path of revolution as his praxis. Marx is fixated on the paradigm of work so as to reduce anything to it. With the findings of the two practical dimensions, Habermas also explained the correlation between the two praxis or actions and the orientation and situation of these actions with two basic human actions (Pusey, 2011), namely: Praxis work with rational-purpose action; Praxis communication with communicative actions; Praxis Power.

Furthermore, by trying to correlate this topic with management science we will find that in the study of science and practice management science includes several forms of action and knowledge and orientation
(Hardiman, 2008). This study also examines the types of actions in management and the form of methodological systematics therein. Rational-purpose action that is solely oriented towards success will require formulas or laws from the empirical-analytical sciences (Naturwissenschaften) to achieve an orientation such as the procurement of a manufactured product by a laborer or a calculating financial manager. regarding expenses and company income. Then communicative action that is oriented towards understanding will require normative knowledge of historical-hermeneutical sciences (geisteswissenschaften) to achieve its orientation such as relationships between employees who respect others indiscriminately or companies that are so adaptive to the surrounding community because of their good cultural or ethical knowledge (Hardiman, 2004).

The latter is strategic action with an orientation that is successful but still has a social or interactive style in its actions that will require assistance from analytical empirical sciences as well as hermeneutical historical sciences to achieve its orientation such as technical understanding of employees obtained by employees from their managers to complete tasks given to be resolved immediately or between customers and sellers who find an agreement after the negotiation process to agree on the price of a product (Agger, 2003). After understanding the complexity between forms of action, orientation, and methodological systematics and the dimensions of Jurgen Habermas with the example the researcherdescribes, Habermas alsomentions thatsurges in one dimension will cause jumps in other dimensions as well. Such surges will only lead to what is called a crisis because jumps in the dimension will also presume surges in the internal of the dimension such as action, orientation, methodological systemic, etc. Therefore we need another dimension which Habermas calls a third dimension capable of controlling surges in other dimensions, finally the ability of the third dimension to control external changes (technical-control dimension) and internal changes (moral-practical dimension). determined by its ability to determine system goals that must be achieved through change, which means that the third dimension is also an important dimension of a rational development (Tobing, 2017)

In short, humans have two dimensions, namely the technical control dimension with work praxis which has a success orientation, and the moral-practical dimension with communication praxis which has a reciprocal 
understanding orientation. However, when there is an imbalance or imbalance in these two dimensions, it will force us to find something that transcends the two dimensions, each of which experiences big jumps that inevitably lead to crises. Habermas proposed something called the third dimension, which can maintain the system. The ability of this third dimension can control spikes in other dimensions, finally, the ability of the third dimension to control external changes (technicalcontrol dimension) and internal changes (moralpractical dimension) is determined by its ability to determine system goals to be achieved. through that change (Hardiman, 2004). Finally, it can be concluded that a comprehensive development is only possible when it comes to three main dimensions, namely the technical dimension, the moral-practical dimension, and the dimension of power. And all three are the rationalization of a development (Viktorahadi 2017). A third dimension is needed to maintain the system and determine the concept in the form of a system to achieve the specified goals: solving existing crises using socialization (Hardiman, 2004).

\section{The dimensions of power are oriented towards emancipation and critical sciences}

The dimension of power as the third dimension that houses two other human dimensions, namely the control-technical and moral-practical dimensions with each orientation of the actions in it must have emancipatory and critical interests to free ideological barriers in other dimensions that trigger crises (Habermas, 1972). In discussing how the possibility of rationalization of one development at the same time for stabilization of internal and external surges, it can be concluded that we can solve the existing crisis through analytical and methodological critical socialization. This presupposes the discovery of science as a means of gaining emancipatory interests and knowledge and the appropriate action to do so. Knowledge which means praxis is only possible when human interests direct that knowledge. Then the frozenness at a dimensional point can be reflected in the handling of a problem that tends to weigh heavily on a methodological basis, either by using historical-hermeneutical sciences or empiricalanalytical sciences. Therefore, Habermas proposed that critical sciences for emancipatory interests be needed to free oneself from ideological barriers (Pusey, 2011).

Previously, the critical sciences referred to by Habermas referred to the ideas of two figures: Sigmund Freud and Karl Marx. From Freud, he took the concept of psychoanalysis as the science that uncovers one's selfdeception, and from Marx, he took Marx's ideologicalcritical discussion to reveal mass ideologies or widespread mass madness (Hardiman, 2004). Freud explained that the id, ego, and superego are often described as humans who want to make decisions and the id plays the role of demons and the superego acts like an angel. Id does not mean devil or devil and superego also does not mean angel or angel. But both are the fruit of our minds. The en represents something pleasant and the superego describes moral values. while the ego is ourselves who will ultimately make a decision or bridge the two thoughts, namely the id and superego (Marcuse, 2018).

The id is the only component of personality that is present from birth. This aspect is fully conscious and includes both instinctive and primitive behavior. Freud said that the source of all psychic energy and a major component of personality is the id. The id is driven by the pleasure principle, which seeks immediate satisfaction from all existing wants and needs. If this need is not immediately satisfied, there will be a sense of anxiety (Marcuse, 2018). The ego is a component of personality that is responsible for dealing with reality. Freud said that the ego develops from the id and ensures that the id impulses can be expressed in ways that are acceptable in the real world (Alwisol, 2019). The ego functions in both the conscious, preconscious, and unconscious minds. The ego works on the reality principle which seeks to satisfy desires in a realistic and socially acceptable way (Alwisol, 2019). The last component that appears is the superego. The superego is an aspect of personality that accommodates all moral internalization standards and ideals obtained from parents and society, which are perceived as right and wrong. Superego provides guidelines for making judgments (Husin, 2018).

However, this project was not followed up by Jurgen Habermas because it would only lead to new oppression in the presence of a single analyst or critic who had an absolute claim to truth. By trying to correlate this topic with management science we will find that in the study of science and practice management science includes three forms of action, knowledge, and orientation (Hardiman 2008). Rational-purpose action that is solely oriented towards success will require formulas or laws from the empirical-analytical sciences (Naturwissenschaften) to achieve an orientation such 
as the procurement of a manufactured product by a laborer or a calculating financial manager. regarding expenses and company income. Then communicative action which is oriented towards understanding will require normative knowledge of hermeneutical historical sciences (geisteswissenschaften) to achieve its orientation such as relationships between employees who respect others indiscriminately or companies that are so adaptive to the surrounding community because of their good cultural or ethical knowledge (Habermas, 1972). The latter is strategic action with an orientation that is successful but still has a social or interactive style in its actions, it will require assistance from analytical empirical sciences as well as hermeneutical historical sciences to achieve its orientation such as understanding the employees that employees get by their managers to complete the tasks assigned to them. completed immediately or between customers and sellers who understand each other in the negotiation process to agree on the price of a product (Klein and Huynh, 2004).

\section{Critical Management Science: Emancipatory Praxis}

Critical science presupposes the fusion of ideologies which become the cause of the freezing of knowledge and interests and actions (a dimension). This means that critical sciences have multidisciplinary and liberating studies. Management science has studies that discuss monologic and dialogical matters with their manifestations in communicative action and strategic or instrumental action. Management science can be called critical if the discussion of its functions and its strategic level is also contained in it concerning emancipatory talks. Then we can also stick to a form of action that we adopt from the perspective of Jurgen Habermas which we can relate to an emancipatory orientation with the methodical system of critical management science, namely emancipatory revolutionary communicative action (Hardiman, 2009). Emancipatory communicative action is only another mention of communicative action, the thing that distinguishes it from communicative action which is only in the normative realm is that emancipatory action is not only fixated on one world but three worlds, namely the world of objective, subjective and intersubjective at the same time, therefore the type of action this is necessary for the third dimension (Hardiman, 2008). The third dimension of critical management science in Figure 2.

This third dimension is equipped with systemic methodological tools and in the form of analytical knowledge oriented to emancipatory interests, actions in this dimension use critical tools aimed at freeing oneself from ideological barriers. Critical sciences which are rooted in Habermas's stance on his epistemology are also attempted to eliminate scientism or the paradigm of logical positivism or subject philosophy which tries to reduce interest and knowledge to dimensions that should not be. Communicative action in the dimension of power is action-oriented to achieve an understanding through the three worlds in common (Habermas, 2019a): The objective world (as a whole of all entities which the correct statement is a possibility); The Social World (as a whole of all relationship regulations interpersonal law); The Subjective World (as a speaker's overall experience where he has special access rights).

Communicative action at this level is an act that is true dialogue and purely social from two or more speakers and listeners who reciprocate and simultaneously file not one but three validity claims (Iwan, 2016). When a listener accepts a speech act, an agreement occurs at least two subjects speaking, and acting for an agreement is only possible when it reaches three levels. as a forum for reaching understanding, speech acts play a role: a. To build and renew the relationship between the two parties, where the speaker establishes a relationship with something in the world of a legitimate (social) order; B. To represent circumstances and events in which the speaker fixes a relationship with an existing condition; C. to show experience, namely to show himself in which the speaker establishes a relationship with something in the subjective world that he is entitled to enter (Habermas, 2018).

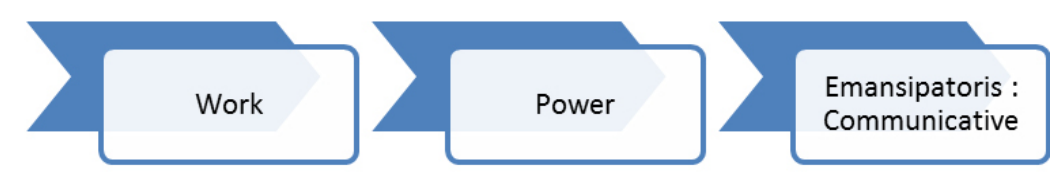

Figure 2. The third dimension of critical management science 
The most basic studies related to planning, organizing, actuating, and controlling as well as strategic analyzes will be more critical when the analysis is successful in capturing the results of the arguments or discourses of actors who state the 3 worlds simultaneously which can be criticized in terms of power for manufacture decisions so that these decisions also presuppose the stabilization and rational development of managerial practices. Emancipatory communicative actions in the dimension of power are actions of subjects who can act and speak so that in achieving consensus they do not agree with things such as manipulation or violence in their social interactions. Then, in practice, critical management science must express ideal speech situations and free from domination and avoid the potential for systematic communication distortion. Emancipatory managerial practice must free the subject of speech to express reflective arguments that cover 3 worlds that can be criticized (Kernstok, 2009).

The embedding of emancipatory communicative action from Habermas' ideas in studies and managerial practices in companies is needed to be more critical and liberating so that it has a strong influence on the formation of other purposeful actions that are based on the results of the preconceived discourse or consensus of communicative action. By relying on critical communicative action, critical management science allows us to be able to presume that there is no 'iron cage' in the company, contrary to reification and allowing more values to live in managerial practice, for example, a company (Agger, 2003). The study of conditions, norms, and freedoms becomes possible in its practices in the company (Kernstock and Brexendorf, 2009). Emancipatory practices presuppose critical sciences so that the rationalization of scientific development and practice of critical management

\section{Discourse: Reflections on Communicative Action and managerial decision making}

Finally, this critical management science can be classified into methodological systematics in an emancipatory dimension of power, such as the company, as an analytical instrument on the three forms of the world at once. However, for this study to be more comprehensive, the researcher will add Habermas' thoughts on reflections on communicative action, namely discourse. Discourse is a reflection of communicative action. At a discursive level, the means we use are argumentative by which we reconsider the previously assumed validity claims. Discourse-related studies will be assisted by legitimacy theory (Hardiman, 2008). The dominant discourse theory will help us to discuss more comprehensively the communicative practices of management science.

Discourse is divided into two, namely; the first is a grounding discourse in which members who speak and act thematically challenge claims of validity with an orientation to obtain normative decisions that are agreed upon by all parties present at that time. So in an organization that upholds cultural values, kinship and even religiosity, it requires a grounding discourse before implementing the program of its activities. The second is a pragmatic discourse in which in this realm people are executors or people discuss how appropriate means are to be used in achieving success orientation or the success of an organization. In this discourse, strategic action is needed for successful goals and language is used to influence other actors for successful outcome orientation. The pragmatic discourse gets legitimacy for the implementation program to be implemented from the results of the basic discourse (Hardiman, 2009). Even though there is a pre-emptive discourse that is strategic in nature, because its legitimacy or basis is the result of a grounding discourse, it can be concluded that even pragmatic discourse rests on the communication paradigm. Then the reports on the activities that have been carried out by the actors from the results of the pragmatic discourse can be used as legitimacy or a basis for a grounding discourse in solving conflicts, considerations and determining the next normative accuracy (Hardiman, 2008).

\section{Role management model at the Mondragon company}

Linking management science and critical sciences, as well as the actions and orientations that follow, does need further discussion if necessary with empirical evidence for it. Therefore, the researcher conducted an empirical study of the Mondragon company which the researcher would make a role model for how to link the critical sciences a la Habermas with the science of critical management which presupposes an emancipatoryoriented third dimension. The Mondragon company is a leading business group in the Basque Country and one of the largest companies in Spain. The company operates worldwide, with 141 production plants in 37 countries, commercial businesses in 53, and sales in more than 150. The mission of the Mondragon Company is 
encapsulated in its Corporate Values: inter cooperation, grassroots management, corporate social responsibility, innovation., democratic organization, education, and social transformation, among others. We are a group of dedicated people with a cooperative identity who form a profitable, competitive, and enterprising business group capable of successfully operating in the global market. The organizational model of Mondragon's company uses democratic methods in its corporate organization, and its objectives are work, the personal and professional progress of its workers, and the development of its community (Burridge, 2012).

Mondragon is the largest Social Innovation Cooperation Ecosystem in the world. Mondragon believes that cooperatives are an effective way to address economic, social, and environmental challenges and transform societies (Stikkers, 2019; Cicopa, 2020). Social Innovation is the main instrument to face the new social and environmental challenges of the 21 st century and to become embedded in the community to listen to and pay attention to the needs of individuals, households, and the community itself, increasing their capacity to act and react (Gutomo, 2018).

Transformative and systemic social innovation. As an ecosystem, Mondragon creates innovative environments with a commitment to improvement, fostering lasting change to solve social problems that are deeply embedded in attitudes and institutions. Organizationally, MONDRAGON is divided into four areas: Finance, Industry, Retail, and Knowledge. It currently consists of 96 separate and independent cooperatives, more than 81,000 people, and 14 R\&D centers, forming a leading business group in the Basque Country and tenth in Spain (Mondragon, 2020).

As the researchers quoted from the official Mondragon website (Mondragon, 2020) which states that:

" MONDRAGON is a cooperative group and always has been. This hallmark is one of its strengths and one of the reasons for its success. One of MONDRAGON's specific traits has been its collective approach, combining the benefits of consensus with the cooperatives' human dimension, creating a robust and supportive cooperative group. 66
Responding to the quotation above, we can understand that the Mondragon Company has a praxis or emancipatory orientation that successfully combines the benefits of consensus with the human dimension (Das, 2014). Then to dissect the vision and mission of the Mondragon company following the vision and mission of the Mondragon company:

Vision:

"Mondragon is Cooperation A cooperative socioeconomic project, with dedicated people working in global companies that are profitable, competitive and entrepreneurial, acknowledged for their human values, social impact, and competitiveness."

\section{Missions:}

"A socioeconomic business project deeply rooted in Basque culture, created by and for people, committed to a sustainable society, greater competitiveness and customer satisfaction, with the remit to create wealth and transform society through business development and employment, It is driven by a commitment. to solidarity, applying democratic methods in its organization and management, It boosts people's engagement and involvement in the management, performance, and ownership of its companies. “

Responding to Mondragon's corporate vision and mission that the company cares about the moralpractical dimension as well as the technical-control dimension of employees in Mondragon's company, therefore the Mondragon project always has a socioeconomic smell that cannot be separated from the Basque culture (Mondragon, 2020). We can see the contents of Mondragon's vision and mission not only talking about how to generate wealth but also how to create emancipatory and egalitarian means of formulating a vision and mission like this, as well as researchers found the value of Mondragon quoted from (Mondragon 2020)'s official website, namely:

"Cooperation: Owners and protagonists, Participation: Grassroots management, Corporate Social Responsibility: Fair distribution of wealth, Innovation: Continuous renewal. Furthermore, based on the Cooperative Principles and its own experience, MONDRAGON nurtures the values of self-motivation and shared responsibility, inter cooperation, social transformation, and good corporate governance practices. “ 
Researchers can find the significance of the vision, mission, values, and practices that are in line with the concept of critical management science that has been reconstructed by the perspective of Jurgen Habermas. It can be said that Mondragon in discovering the vision, mission, and values of his company is not only concerned with the single thinking of one person with manipulative strategic actions or rational-purposeful actions that are full of natural formulas but all originate from communicative actions that view all employees equally so that they are involved. Human resource management can be started by optimizing leadership and managerial functions that focus on ways of working, work mindset, and values. Acculturation of work methods, mindset, and values from the three generations which is illustrated by the formation of a persistent way of working (persistence) with a multidisciplinary approach and not giving up easily, then from the mindset that is built the formation of transparency and fairness for the appreciation of each achievement, while in terms of understanding the value of the vast potential space for creativity and innovation that arises collectively with a sense of solidarity to determine consensus. In the end, all work together on mutual understanding between the communicative actions of the company's stake holders so that when they get wealth their instrumental works will still be filled with human or critical and emancipatory values (Hardiman, 2008).

The images we get from the MONDRAGON company are how the deliberative procession is reflected by the basic discourse of the members to determine a normative determination whose results from these decisions become the basis for the execution of MONDRAGON's corporate strategic planning. This ultimately reflects the value of MONDRAGON, which has a socio-economic character and am Then the evidence of how the pragmatic discourse works well in the MONDRAGON company can be seen from how the concrete technical implementation of the MONDRAGON company is; having so many members, expanding its types of industries, high profitability, having an impact on the city and state economy and not forgetting its ideas regarding transformative and systemic social innovation (Mondragon, 2020).

\section{Implication managerial}

The organizational model of the Mondragon company uses democratic methods in its corporate organization, and its objectives are the completion of tasks and obligations at work, enhancing personal and professional progress for both its employees and the company, and the development of its community (Brookes, 2011). We may derive from Habermas's communicative action theory that unity allows an organization to shape a political action, allowing organizations that function for instrumental performance to provide a moral foundation on which to transfer actors mechanically (Habermas, 2019b). Furthermore, based on Habermas' study, it can be concluded that if an organization employs the logical Mondragon model in its practice, the growth of human intelligence would have a significant effect.

\section{CONCLUSIONS AND RECOMMENDATIONS}

\section{Conclusions}

In practice, management science tends to be positivistic, which eventually causes a person to fall into a reified or reified mindset. However, the unique thing about management science itself is that it has the potential to break the ice that is created. Management science, after being reconstructed with Jurgen Habermas' perspective, can become a critical and emancipatory multidisciplinary study, meaning that management science can become a valuable and liberating study as proven by this science which has emancipatory praxis. Then we can see the discussion or study of management science which includes actions from the Habermas perspective, namely communicative action, rationalpurposeful action, and strategic action. Management science uses strategic action and rational action with purpose when studying objective circumstances and uses communicative action in its normative realm to suit its claim of appropriateness with cultural values or interaction structures. The insert from Habermas's perspective, namely emancipatory communicative action in the emancipatory third dimension, makes management science more critical because its study allows 3 forms of the world, namely the objective, subjective and intersubjective world for the validity of the claims expressed simultaneously (Habermas, 2019a). Because with such emancipatory discussion it is possible to form rational development in practice and critical management science. Then Habermas's 
intellectual journey helps us with discourse theory and legitimacy theory as concrete praxis and practice for critical management science. Appointing Mondragon to be a role model will make it easier for us to prove that the idea of critical management science in management also supports people's views regarding the profitability and strategy of the company or organization because Mondragon in his concise conceptualization of critical management because it reflects the vision, mission, and values that hold on to humanity. , equality and solidarity with a democratic method that also generates significant profitability while upholding emancipatory values.

\section{Recommendations}

The descriptions that we get from the Mondragon company are how the procession is reflected by the members to determine a normative decision which results from the decision being the basis for Mondragon corporate strategic planning. This should reflect the value of Mondragon which has a socio-economic character and has management known as grassroots management, this management is expected to have an impact on so many members, high profitability, and hopefully transformative and systemic social innovation. From the vital model of connecting with society, traditions, and basic unity to the key issues explored in sustainability, organizations all over the world will learn from what Mondragon is doing. The stakeholders or a minimum of representatives of an association must be involved in the creation, improvement, and development of the organization based on shared understanding.

\section{REFERENCES}

Adorno T. 2014. Dialektika Pencerahan: Mencari Identitas Manusia Rasional. Yogyakarta: ircishod.

Agger B. 2003. Teori Sosial Kritis : Kritik, Penerapan Dan Implikasinya. Yogyakarta: Kreasi Wacana.

Alwisol. 2019. Psikologi Kepribadian. Malang: UMM Press.

Bengtsson M. 2016. How to plan and perform a qualitative study using content analysis. NursingPlus Open 2: 8-14. DOI: 10.1016/j. npls.2016.01.001

Brookes S. 2011. Crisis, confidence and collectivity: responding to the new public leadership challenge. Leadership 7(2):175-94.
Burridge T. 2012. Basque Co-Operative Mondragon Defies Spain Slump. BBC News, Arrasate, Spain

Cicopa. 2020. Mondragon Corporation Is Ranked 11th in List of Enterprises That Are Changing the World.

Das, Ashok B. 2014. Ethical consequences : treatment of stakeholders in capitalistic approach and cooperative approach to business. European Journal of Business and Management 6(23):6468.

Griffin R. 2007. Manajemen Jilid I Edisi 7. Jakarta: Erlangga.

Gutomo, Adjie. 2018. “engenal Koperasi Mondragon Spanyol - Mondragon Cooperative.https:// pipnews.co.id/mancanegara/mengenal-koperasimondragon-spanyol-mondragon-cooperative/.

Habermas J. 1972. Knowledge and Human Interest. Jerman: Polity Press.

Habermas J. 2018. KONSTELASI PASKA-BANGSA : Esai Esai Politik. Bantul: Kreasi Wacana.

Habermas J. 2019a. Teori Tindakan Komunikatif I: Rasio Dan Rasionalitas Masyarakat. Bantul: Kreasi Wacana.

Habermas J. 2019b. Teori Tindakan Komunikatif II : Kritik Atas Rasio Fungsionalis. Bantul: Kreasi Wacana.

Hardiman F. Budi. 2004. Kritik Ideologi - Menyingkap Kepentingan Pengetahuan Bersama Jurgen Habermas. Yogyakarta: Buku Baik.

Hardiman, F. Budi. 2008. Menuju Masyarakat Komunikatif: Ilmu, Masyarakat, Politik Dan Postmodernisme Menurut Juergen Habermas. Tangerang: Kanisius.

Hardiman F. Budi. 2009. Demokrasi Deliberatif: Menimbang 'Negara Hukum' Dan 'Ruang 'Publik' Dalam Teori Diskursus Jürgen Habermas. Yogyakarta: Kanisius.

Hardiman, F. Budi. 2010. Ruang Publik: Melacak "Partisipasi Demokratis" Dari Polis Sampai Cyberspace. Yogyakarta: Kanisius.

Hardiman F. Budi. 2018. Demokrasi Dan Sentimentalitas : Dari "Bangsa Setan-Setan", Radikalisme Agama Sampai Post-Sekularisme. Yogyakarta: Kanisius.

Hidayat H, Sukmawati A, Eriyatno. 2020. Model pengelolaan sumberdaya manusia berbasis kompetensi era industri 4.0. Jurnal Aplikasi Manajemen dan Bisnis 6(3):1-12.

Husin H. 2018. Id, ego dan superego dalam pendidikan Islam. Al Qalam: Jurnal Ilmiah Keagamaan Dan 
Kemasyarakatan 11(23):47.

Irfaan S. 2009. Jurgen habermas: problem dialektika ilmu sosial. Journal article Komunika 3(1).

Iwan. 2016. Menelaah teori kritis jürgen habermas. Edueksos : Jurnal Pendidikan Sosial \& Ekonomi 3(2):145-65.

Kernstock J, Tim OB. 2009. Implications of habermas's 'theory of communicative action' for corporate brand management. Corporate Communications 14(4):389-403.

Kernstok J, Brexendorf T. 2009. Implications of habermas's 'theory of communicative action' for corporate brand management. Corporate Communications: An International Journal 14(4):389-403

Klein HK, Huynh MQ. 2004. The critical social theory of jürgen habermas and its implications for IS research. Social Theory and Philosophy for Information Systems (February):157-237.

Krippendorff, K. 2004. ContentAnalysis An Introduction to Its Methodology (2nd ed.) Thousand Oaks, CA Sage Publications.

Marcuse H. 2018. Eros Dan Peradaban: Sebuah Telaah Filosofis Tentang Freud. Yogyakarta: Tanda Baca.
Maulana I. 2020. Kepemimpinan kolektif era pandemin di Indonesia. Management and Business Review 4(1): 32-38.

Mondragon. 2020. Situs Resmi. https://www. mondragon-corporation.com/en/about-us/.

Nuris A. 2016. Tindakan komunikatif : sekilas tentang pemikiran juergen habermas. Al-Balagh : Jurnal Dakwah Dan Komunikasi 1(1):39.

Priastana Jo. 2012. Teori Tindakan Komunikasi Jurgen Habermas Sebagai Titik Pijak Dialog Antar Agama. Depok: UI

Pusey M. 2011. Habermas: Dasar Dan Konteks Pemikarannya. Yogyakarta: Resist Book.

Robbins S. 2016. MANAGEMENT FOURTEENTH EDITION 14E. Pearson.

Stikkers KW. 2019. Dewey, economic democracy, and the mondragon cooperatives. Munich Personal RePEc Archive1(April):0-15.

Tobing, Melati M. 2017. Jurgen Habermas Dan Ruang Publik di Indonesia. Jakarta: UKI.

Viktorahadi B. 2017. Kritik jürgen habermas terhadap peran dan fungsi agama dalam. Theologia 28(2):273-98. 